\title{
A Discussion on Affordable Housing Projects; Case Study Mehr Housing, Iran
}

\author{
* Ph.D. Candidate MARYAM GHASEMI 1, Dr. NAZIFE ÖZAY ${ }^{2}$ \\ 1, 2 Department of Architecture, Eastern Mediterranean University, Famagusta, via Mersin 10, Turkey \\ 'E mail: maryam.ghasemi@cc.emu.edu.tr, 2E mail: nazife.ozay@emu.edu.tr
}

\section{ARTICLE INFO:}

Article history:

Received 15 July 2018

Accepted 23 September 2018

Available online 13 October

2018

Keywords:

Affordable Housing,

Low-income,

Iran,

Mehr Housing,

Architectural Quality.
This work is licensed under a Creative Commons Attribution - NonCommercial - NoDerivs 4.0. "CC-BY-NC-ND"

\begin{abstract}
A B S T R A C T
Housing is one of the basic needs for humans. Families in different countries with various cultures, who have different life styles respond to their individual needs including physical and mental in a safe place that is called house. The world population is increasing day by day. In parallel to this population growth, housing demand increases rapidly. Thus, different countries try to meet the needs of housing by creating multifarious housing policies. Generally, these policies have been developed according to countries' special conditions and the developments in the world. Iran is also a country, which has a rapid population growth and has developed series of policies to solve the housing problems. Affordable housing is one of solution for providing the house by governments. These type of houses is the ways to answer the demand for low-income people or the people that their income is not sufficient to owner a house. Since 2007, government has built new type of affordable housing in different cities of Iran. These houses are named as Mehr Housing, which are generally medium and high-rise buildings for low-income people. In this study, it is intended to make an evaluation about the strengthens and weaknesses of Mehr Housing projects in Iran in terms of housing quality. In order to evaluate the architectural quality of Mehr Housing projects in Sarvestan, Abadeh, Nourabad, Firoozabad, Hashtgerd, Zahedan, Tabriz, Hadishahr, Marand, Zanjan, Yazd and Natanz physical analysis method is used as well as literature review. These analyses are mainly done based on location and accessibility, safety and security, public open spaces and recreational activities, plan layout of housing units and physical features. By this discussion, it is expected to create a guidance for the policy makers, designers, users and other shareholders.
\end{abstract}

Journal Of CONTEMPORARY URBAN AFFAIRS (2018), 2(3), 137-145. https://doi.org/10.25034/ijcua.2018.4728

www.ijcua.com

Copyright (C) 2018 Journal Of Contemporary Urban Affairs. All rights reserved.

\section{Introduction}

From the ancient time till now, one of the most important needs of human after the food is shelter. Dwelling could protect people from cold and hot weather, risk of animals and in other words a safe place for resting and comfort (Weihe, 1990). Besides, housing meets the psychological and social needs of users (Evans, 2003). Due to increasing population of

*Corresponding Author:

Faculty of Architecture, Department of Architecture, Eastern Mediterranean University, Famagusta, Northern Cyprus

E-mail address: maryam.ghasemi@cc.emu.edu.tr 
the cities and suburban areas after the Industrial Revolution, the housing become one of the most important and essential problem of people (Aldrich, 1995).

The most important factors, which help to solve lack of housing is supplying the land, attention to the construction material and powerful management (Mazloom Khorasani, 2011). Housing problem exists in every country. However, it is more serious in third world countries related to political, economic, social and cultural factors (Pour Mohammadi, 2014).

From the other point of view since the adoption of the Universal Declaration of Human Rights in 1948, "the right to adequate housing" was introduced as an important component of "good living standards" (Assembly, 1984). Thus, each government imposed special rules and regulations in field of housing (Schill, 2005). They take action to establish ministries of housing in order to allocate funds and policy formulation, regulation, programs and special projects in the housing sector (Hulchanski, 2002).

As a developing country, Iran also has special effort on housing problem. The first attempt in this way is creation of the Ministry of Prosperity in (1964). After that, the Department of Housing and Urban Development was established in 1974 (Rasoolimanesh, 2013). Furthermore, according to the agenda of Second Conference on Human Settlements (Habitat 2) United Nations Ally, which was organised in Turkey in 1996. Islamic Republic of Iran as a member accepted some commitments. These can be summarized as regarding the right to adequate housing, enabling all people have access to appropriate shelter. The other factor in this agenda is to provide legal security for land ownership, mobilizing financial resources and credit and other sources of private and government sectors for social development access to efficient technologies and effective practices (Nastaran, 2010). The right of housing in the constitution stated clearly in Iran. According to 31 th of the constitution of the Islamic Republic of Iran, it is the right of every person and household in Iran to have a house. Government is responsible for those, whose need according to priority. Workers and villagers are the first ones that can benefit from the implementation of the realization of this principle (Saremi, 2012).

In socialist countries, despite they produced too many houses but based on increasing housing demand, they still have lack in housing. On the other hand, qualitative indicators in the houses are not suitable (Pugh, 2001).

Housing in developing countries also has problems. The fundamental issues of these countries which is the result of use of poor materials in construction, insufficient access to electricity, water and sewage systems (Okpala, 1992). Most of these countries face by the housing illegal production. Sometimes this figure reaches 50 to 75 percent of urban housing units (Azizi, 2004). One of the countries which is faced the housing problem in recent decades is Iran. This problem happened especially after the land reform in 1962 and after the changes in production methods with the growing trend of urbanization (Hesamian, 2004).

With the revolution in Iran in 1979, there is no any control on the spread of the cities. Housing in the suburbs gets much more flourished and the tenants that renting the house had much more problem with the rent price. The immigrant from the rural part get settled in the suburb areas (Sharifinia, 2012). In that period house is constructing for personal use not for giving to rent. After the Islamic revolution in terms of quantity the construction of the houses increased but the amount of investment decrease. Because the size of the houses got smaller. With the imposed war the building activities decrease and investment get lower than before in the years 1982 and 1983 (Ahari, 1996). There are five programs which were developed after the revolution that in first program the goals are related to the changing the composition construction practices to reach the durable buildings, promotion of housing inventory per capita in the country and directing the production of better quality housing with less infrastructure. The goal of second program is clean policy that is consisting of saving, mass construction and miniaturization (Ghanbari, 2010). The goal of third programme are reducing the average floor area of housing and reduce destruction of dwellings. The goal of fourth program are balance to adequate housing among groups and regions of the country, provide housing for low-income households, provide housing for youth and female headed households and industrialization of the houses construction. The goal of fifth program are housing for lowincome people, safe and durable housing, market regulation and coordination between housing policies and land use planning and development in policies and reducing regional disparities (URL1).

Provide housing in recent decades, have been one of the most important problems of various segments, especially for low-income families. Population growth and increasing tendency to urbanization and migration from villages to cities after the revolution in Iran, use of less 
durable materials, the entrance of young age of applicants to mortgage market and optimum combination of investment and regional disparities shows housing problem more acute than ever (Rezaie, 2015). Due to the conditions, which is mentioned above, caused to raising affordable houses as a solution for this country in the second and third economic development plan which is related to the social and cultural rights. Mehr housing is an affordable type of house which is belong to the fourth development plan (Saeedi, 2011). Base oN this argument, is to analyse Mehr housing projects in terms of safety and security, location and accessibility, plan layout of housing units and physical features, public open spaces and recreational activities. Finally, a discuss is done on the weakness and strengthens in these projects.

\section{Literature Review}

\subsection{Theoretical Background}

The best definition for affordable housing is related to the description which is done by the Department of Housing and Urban Development (HUD). It is defined as a type of house that bring ability to the households to bring the opportunity to have a house (O'Neill, 2008). By this opportunity the household shouldn't pay more than 30 percent of the house price (Kutty, 2005). There are different plans for affordable housing that is categorized as: 1. homeownership assistance, 2. rental assistance and 3 . Land use and regulatory incentives. In these three models, governments are helping families to have a low-income renting house. Also, it is preparing the lowinterest loans to get easier homeownership (Katz, 2003).

There are different studies related to the affordable and low-income housing in the world. Devrim (2016) studied the transformation of Toki houses in last twenty years. These types of houses have a unique demographical distortion of the morphological texture in big contemporary Turkish cities. One of the weaknesses of TOKI houses is the similarities in architecture and urbanity. These projects are governmental profit- oriented. Wang and Murieh (2011) mentioned about the policy change in China had effect on social housing system. It gets more active and the marketing gets dynamic. However, it has brought problems in characteristic of market economies.

Satisfaction in residents can be used as a key predictor of a personals realization of the "quality of life" and also inadequate in their housing environment and progress to the status quo. It is also key predictor of success of private and public constructors. Finally, it has affect on housing demand and neighbourhood change (Djebuarni \& Al-Abed, 2000).

The study related to the satisfaction done by A.M.M. Liu in 1999. It was related to the Post occupancy evaluation in satisfaction. The paper study the social and physical factors that influence the satisfaction in housing estate, Hong Kong. The comparison between the private and public housing dissatisfaction were done about the housing occupants.

Abedini (2013) study which is titled as "Assess public housing policies in relation to afford urban low-income households in Iran (Urmia city), is analysed the Mehr housing in relation to the afford of low- income families in the Urmia city. Also, the public housing policies which is applied by the government for low-income people were discussed.

\subsubsection{Mehr Housing Projects in Iran}

Mehr housing is a kind of project which were started to be designed in 2007 . The main goals are to bring equality in between supply and demand for housing by omitting the land price, housing for low-income people and poor people, control and prevent the skyrocketing the prices of lands and housing, housing boost production and increase production volumes of housing and reducing the cost of housing (Rent, mortgage and buy). Also, it is aimed to give solution for the future housing needs, justice in access to adequate housing. Consequently, poverty reduction and housing for youth was raised (Karshenasan, 2013). Mehr housing projects are mainly located in three regions: New cities, Lands around cities and old areas to facilitate modernization and improvement (Rezaie, 2015).

Mehr housing is a big project that will be consist of one million and five thousands of housing units. These amount of units will cover six million population of the country, which is approximately $12 \%$ of urban population. Mehr houses are constructed in collaboration with various organizations such as: Ministry of Housing, Housing Foundation, Ministry of Cooperatives, Central Bank, Municipalities and Central Insurance (Shahri, 2015).

Zanjani (2011) in his research mentioned the principles which were considered in Mehr Housing plan. 1. The Mehr houses should be constructed like mass housing production. 2 . They are downsizing. 3. Some of them are high rise buildings which help to have more unit. 4 . These projects aim to saving construction site and energy. 5. It is aimed to reduce cost by using technical principles. 6. They use public 
space and common space. 7. They have good views.

The ones that have responsibility of Mehr housing construction projects are members of housing cooperatives and is mainly concerned with their own participation. Besides, the government by giving them free land as well as granting long-term loans plays supporting roles (Isalou, 2014). They try it to do it by mass housing construction in the form of cooperatives housing for 50 to 500 people. 20 percent of primary cost of this type of housing is financed through savings and participation of applicants (Zanjani, 2011 ).

\section{Methodology}

The data for this study is collected based on literature review, observation and physical analysis. The cities of the projects are selected due to their size and location (Table 1). Sarvestan is a rural-city. Hadishahr and Natanz are small cities. Abadeh, Nourabad and Firoozabad are medium size cities. Hashtgerd, Yazd, Zahedan and Zanjan are large cities and Tabriz is categorized as a metropolitan city. However, these cities are belonging to different province from North West to South East part of Iran. Sarvestan, Abadeh, Nourabad and Firoozabad, are four cities which belong to Fars province. Hashtgerd is from Alborz Province. Zahedan is from Sistan and Baloochestan Province. Tabriz, Hadishahr and Marand, are from Azarbayejane sharghi Province. Zanjan is from Zanjan province. Yazd is from Yazd province and finally Natanz is from Esfahan province (Fig.1).

This study is intended to define the general weakness and strengthen point of the selected Mehr housing projects. The architectural quality of Mehr housing projects are aimed to be evaluated in terms of location and accessibility, safety and security, public open spaces and recreational activities, plan layout and functions, physical features.
Table 1: Selected cities (population and size)

\begin{tabular}{|l|l|l|}
\hline Cities & Population & Category \\
\hline Sarvestan & 18.187 & Rural-City \\
\hline Hadishahr & 34.346 & Small city \\
\hline Natanz & 42.239 & Small city \\
\hline Abadeh & 100.831 & Medium size city \\
\hline Nourabad & 117.527 & Medium size city \\
\hline Firoozabad & 121.417 & Medium size city \\
\hline Marand & 156.873 & Medium size city \\
\hline Zanjan & 521.302 & Large city \\
\hline Zahedan & 587.730 & Large city \\
\hline Hashtgerd & 650.000 & Large city \\
\hline yazd & & Large city \\
\hline Tabriz & 682.582 & Metropolis \\
\hline
\end{tabular}

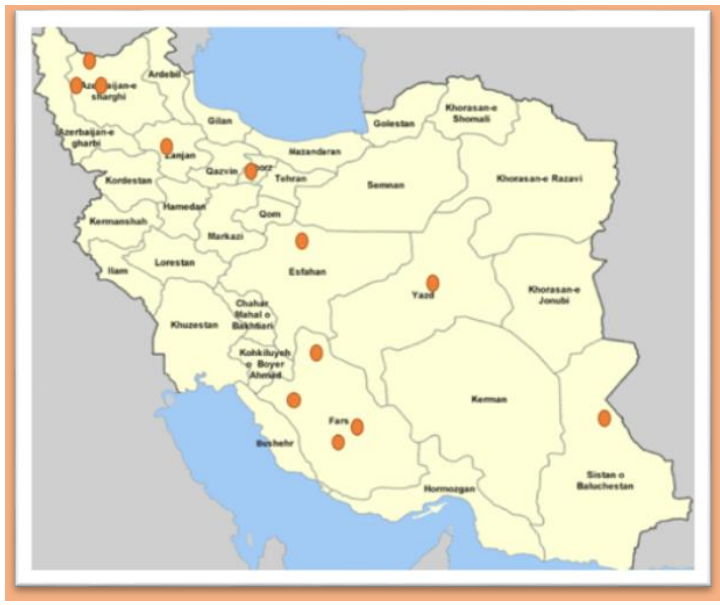

Figure 1: Selected cities on the map of Iran.

\section{A General Discussion on Architectural Quality of Mehr Housing 4.1. Location and Accessibility}

There are three type of location in Mehr housing Projects as mentioned before in this study. Some of them are located outside of the cities (Fig.3) and some of them are inside the city (Fig. 2).

In Mehr housing projects the ones that locating inside of the cities have much more benefit than the ones that are located outside of the cities. They have better access to transportation facility but Mehr houses that are located in suburbs suffer from the lack in transportation facility. The users are complaining about shortage in different type of transportation system. Most of the tenants in Mehr houses in suburbs are workers in other cities and the big cities next to these suburbs projects. Karimzadeh (2015) study Abadeh and Sarvestan Mehr houses, Droudi (2014) study Pardis Mehr houses and Rafieeyan (2014) also study the Zahedan Mehr houses. All of them mentioned in their studies that the Mehr 
housing projects which are located in suburbs, the tenants suffer for transportation issue.

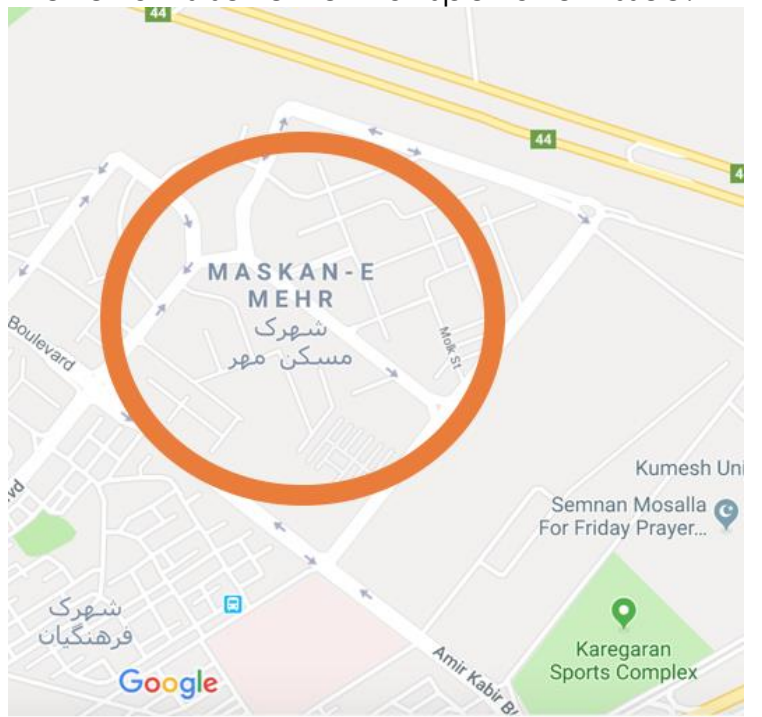

Figure 2: Semnan Mehr housing inside the city (URL 2)

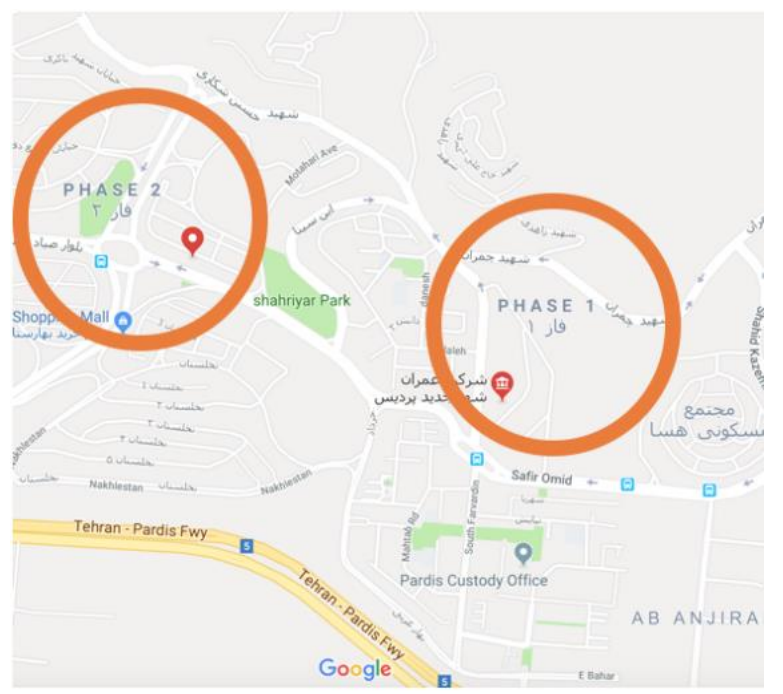

Figure 3: Pardis Mehr housing outside of the city (URL 2)

\subsection{Locational Features}

Mehr housing projects that are located in the cities have access to different facilities such as educational, entertainment, bazars, sport and health facilities. They have also access to gas, electricity, water, telephone and sewage system. However, the projects which are located in the suburbs suffers from lack of access to entertainment, health, educational, bazars, and sport facilities. Some of the projects have lack in access of gas, water, electricity and telephone. Also, Rafieeyan (2014), Droudi (2014), Ghanbari (2013) and Pour Mohammadi (2014) in different studies on Mehr housing projects out of the city in suburbs was mentioned that the citizens have problem with the lack of facilities in suburban areas. It is better to locate these projects near the big cities to reduce the price that should pay for infrastructure for Mehr housing projects in suburbs. Citizens for satisfying their need they should use urban trips which bring wasting time and money for low-income people. It should be more attention in the selecting of the land. Because in these projects the lands are outside of the city and suddenly the city extended without any programmed plan.

\subsection{Safety and Security}

All of the Mehr housing Projects have governmental insurance. One of the most important factor that should be considered in design is, obey all the rules and regulation to construct a building which is protected from earthquake. Mostly, these houses are not constructed and located based on environmental factors and natural environment. If in theses projects natural disasters happened, they do not have any facilities to support the people who are living in these complexes. Ghanbari (2013) also stated in his study, the projects in these three cities such as Tabriz, Hadishahr and Marand, were not designed by considering the environment factors. None of the mentioned projects are located due to protecting from earthquake. For example in Neyshaboor earthquake in 2017 all of the housing units were destroyed (Fig. 4). These apartments are not constructed based on earthquake rules and regulations.

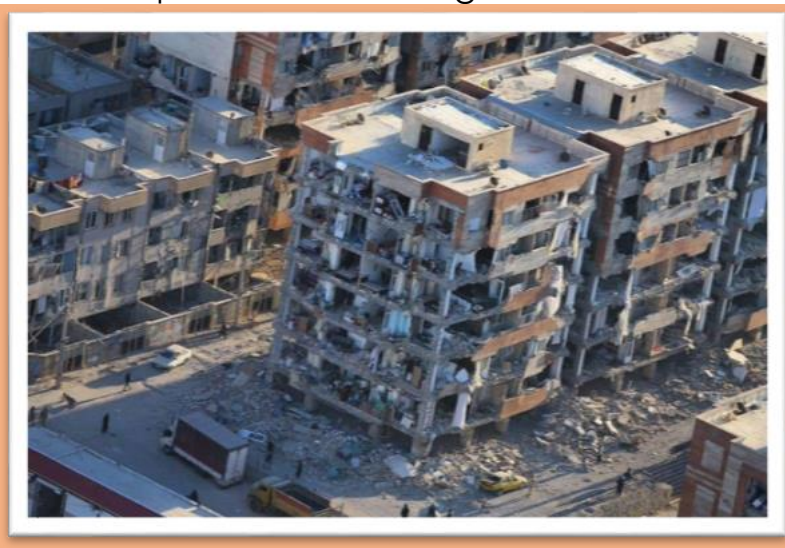

Figure 4: Mehr Housing in Neyshaboor (URL 3).

From other point of view there are too many families with different cultures that caused raise of crime so easily. The projects which are located in suburbs, have more percentage of crime compare to the ones that are locating in cities. Besides, Mehr housing projects have no any security person and also there is no any security camera.

\subsection{Public Open Spaces and Recreational Activities}

The other factor that is very important in Mehr housing project is, having public spaces and recreational activities around these projects. The projects that are locating in the city have access to park and green areas. Under the influence of the Islamic religion, the way of life 
is more introverted. Thus recreational areas such as park, open spaces, semi open spaces in these projects provide social communication. This situation cause increasing rate of marriage and decrease the rate of divorce as Pour Mohammadi mentioned in his study in (2014). However, in projects that are locating in suburb areas, they have lack in public open spaces such as gardens, parks and playground for children. Rafieeyan (2014) mentioned in his study, the quality of the houses can be improved by the green spaces. However, in parallel to this issue, the gathering from different cultures in these public areas could raise the crime, specifically among teenage and children. This situation forces the children to spend much more time together and raise the crime among them. From the other view suburb areas have much more potential for existing the crime than the projects that located inside the city. Karimzadeh (2015) by study Sarvestan and Abadeh Mehr houses project and Droudi (2014) by study Pardis Mehr house project also mentioned that the projects they analysed they have cultural problems.

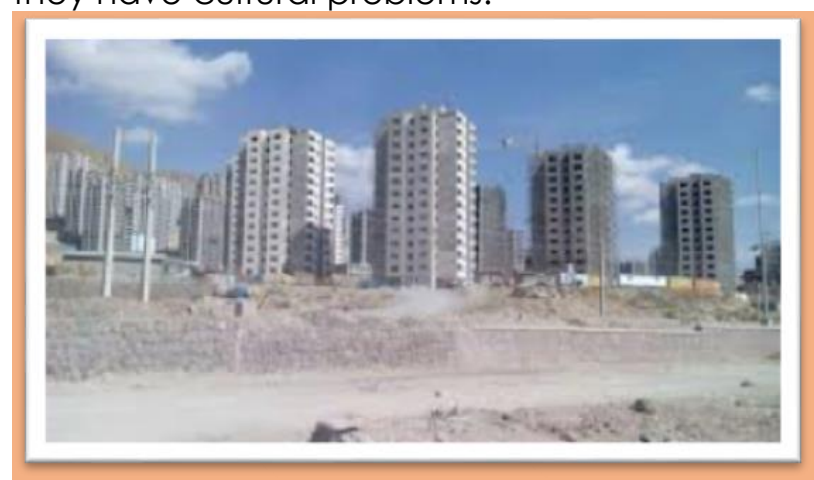

Figure 5: Pardis Mehr housing in suburbs area (URL 4).

\subsection{Plan Layout and Functions}

There are different plan types in Mehr housing project. These apartments are categorized as high rise and medium rise buildings. The plans of Mehr housing projects should be suitable for the population density and also culture of the city. They should be designed by considering the climatic factors of different cities and sun orientation. As Soltani (2014) stated in his study, the citizens are not satisfied with design of their units due to the climatic factors. By constructing these types of houses the number of the detached and semi-detached houses are reduced. That also extends the cities without any program. These type of apartment buildings could be beneficial for the use of different number of families that have specific square meter in the same time by constructing in the same land. Also, Pour Mohammadi (2013) stated in his study about this situation in
Zanjan city. One of the most important problem related to Mehr houses is that all of them are designed mostly look like each other. There is no any attention to the specific cultural and climatic factors in these houses.

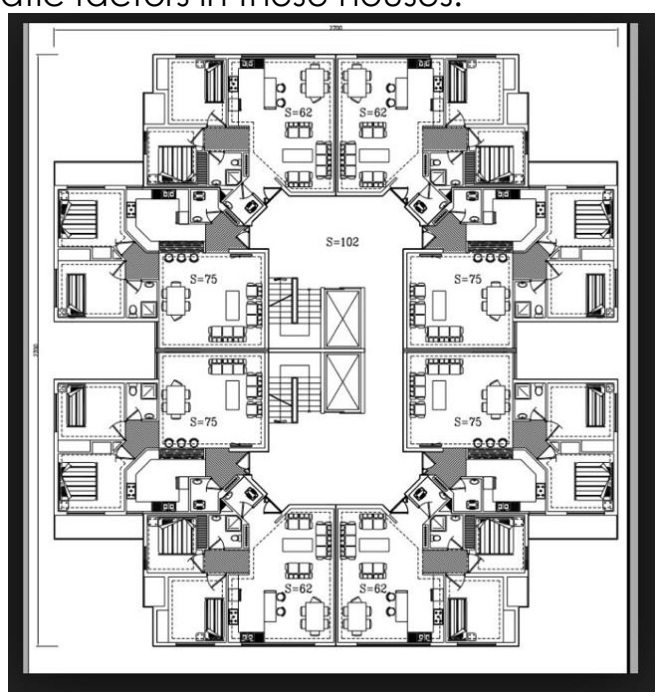

Figure 6: Type of plan for high rise Mehr housing project in Pardis city (URL 5).

In this plan there are two type of units. One of them is 75 square meter. The other one is 62 square meter. Both of them are two bedrooms and they have one toilet and one bathroom. The kitchen belong to these units is an open kitchen. Due to the Iranian culture, this type of kitchen is not suitable. Most of the Mehr housing projects have two bedrooms. Generally, plan schemes of the Mehr Housing projects are same in different cities. Generally, this type of houses (two-bedroom type) are suitable for the small sized families such as with one or two children. However, the families that they have more than two children they need bigger housing units to satisfy their needs and necessities.

\subsection{Physical Features}

These houses should be protected from the earthquake and the isolation system to make the structure gets more durable. The total cost of Mehr house projects are not high. They don't spend too much money in the appearance. Thus, it could be affordable for low-income people. So mostly contractors choosing to use low quality material. Most of them are look like each other and they have same material in different type of climate in Iran (Fig .7, 8). Most of the doors and windows are same type. By this issue they reduce the satisfaction of the citizens. They should give attention to the sewage disposal system. Droudi (2014) also stated that the other important factor is to have good lighting and good view in Mehr housing projects. Generally, in Mehr housing projects there is a semi open balcony for each 
flat. In parallel to the religion of this country, generally the families have more privacy and they are not using these semi open spaces as a socialising area. They are generally using for storing the staffs or organizing them as a small green area.

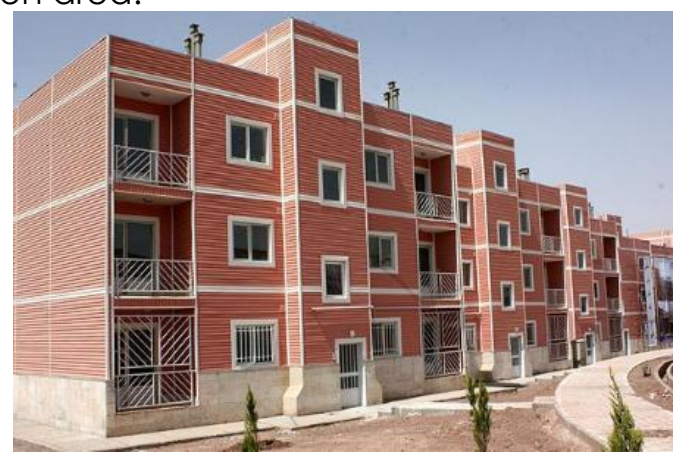

Figure 7: Mehr housing project in Alborz city (author)

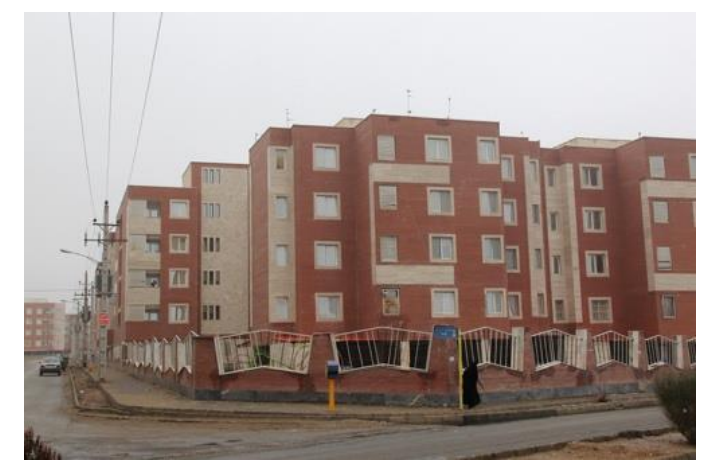

Figure 8: Mehr housing project in Semnan city (author)

Table 2: General weaknesses and strengthens of Mehr houses.

\begin{tabular}{|c|c|c|}
\hline Factors & Weakness & Strengthens \\
\hline Accessibility & $\begin{array}{l}\text { Lack of access to public } \\
\text { transportation in suburb } \\
\text { projects }\end{array}$ & $\begin{array}{l}\text { Access to public } \\
\text { transportation in city } \\
\text { centre projects }\end{array}$ \\
\hline $\begin{array}{l}\text { Locational } \\
\text { Features }\end{array}$ & $\begin{array}{l}\text { Lack of access to } \\
\text { educational, bazars, } \\
\text { entertainment, health, sport, } \\
\text { water, telephone, gas and } \\
\text { electricity facilities in suburb } \\
\text { projects }\end{array}$ & $\begin{array}{l}\text { Access to educational, } \\
\text { bazars, entertainment, } \\
\text { health, sport, water, } \\
\text { telephone, gas and } \\
\text { electricity facilities in } \\
\text { city centre projects }\end{array}$ \\
\hline $\begin{array}{l}\text { Safety and } \\
\text { Security }\end{array}$ & $\begin{array}{l}\text { Raise of crime in suburbs } \\
\text { area projects, no any } \\
\text { security person and security } \\
\text { camera in both type of city } \\
\text { centre and suburbs projects, } \\
\text { they don't consider } \\
\text { earthquake }\end{array}$ & $\begin{array}{l}\text { All of the projects have } \\
\text { governmental insurance }\end{array}$ \\
\hline $\begin{array}{l}\text { Public Open } \\
\text { Spaces and } \\
\text { Recreational } \\
\text { Activities }\end{array}$ & $\begin{array}{l}\text { Children gathering from } \\
\text { different culture make raise } \\
\text { the crime in public areas in } \\
\text { suburbs project }\end{array}$ & $\begin{array}{l}\text { Access to park and } \\
\text { green areas in city } \\
\text { centre projects }\end{array}$ \\
\hline $\begin{array}{l}\text { Plan Layout and } \\
\text { Functions }\end{array}$ & $\begin{array}{l}\text { Plans are not suitable for the } \\
\text { population density and also } \\
\text { the culture of the specific } \\
\text { city and not respecting the } \\
\text { climatic factors }\end{array}$ & $\begin{array}{l}\text { They answer the } \\
\text { average needs of the } \\
\text { users }\end{array}$ \\
\hline Physical Features & $\begin{array}{l}\text { Poor sewage disposal } \\
\text { system, low quality in } \\
\text { choosing material, have } \\
\text { same material in different } \\
\text { type of climate }\end{array}$ & $\begin{array}{l}\text { Industrialized } \\
\text { construction system }\end{array}$ \\
\hline
\end{tabular}

\section{Conclusion}

Today having affordable house is an essential need for every type of families, which belong to low-income group. This study analyses the Mehr affordable housing projects in different province with different population. This policy with the aim of creates housing for low-income people by omitting the land price try to solve the housing problem in Iran. However, these projects have some strengthens and weaknesses based on different factors such as location and accessibility, safety and security, public open spaces and recreational activities, plan layout and functions and physical features. Lack of access to public transportation, entertainment, market, educational and health facilities and also raising crime in suburb type Mehr housing projects are some of the weaknesses. By this study on the selected cases, it is obvious that it is no matter how is the density of the population in different cities, they have common problems in general.

The architectural qualities of the Mehr housing projects can be developed by considering cultural aspects such as Iranian life style and appropriate functional spaces in proper sizes. Also, environmental factors need to be analysed during the design process. For the housing groups that are far from the cities, the necessary social, educational, health and recreational activities can be provided. Besides, the architectural identity of these housing groups needs to be considered during the design and construction processes.

Generally, this type of houses (Two-bedroom type) are suitable for the small sized families such as with one or two children. The use of the industrialized construction system which is providing more economical and easy production in a shorter time is one of the strengthen of these Mehr houses projects. Besides, the groups which are located in the cities have an access to the social, educational and entertainment activities.

\section{Acknowledgement}

This research did not receive any specific grant from funding agencies in the public, commercial, or not-for-profit sectors.

\section{References}

Abedini, A. (2013). Assess public housing policies in relation to low-income households afford in Iran (Case Study: Orumiyeh) (Unpoplished master's thesis) . Tabriz University,Tabriz, Iran. http://idochp2.irandoc.ac.ir/FManage/DelFutx ? $\mathrm{kno}=217489 \& \mathrm{type}=\mathrm{th}$ 
Ahari, Z., \& Amini, S. (1996). The Experiences of Different Countries in the Provision of Housing. Tehran, Iran: National Land and Housing Organization-Tehran Plan, Fourth Development, Economic, Social and Cultural. http://grup.journals.pnu.ac.ir/article 3779.html

Aldrich, B.C. \& Sandhu, R.S. eds. (1995). Housing the urban poor: Policy and Practice in Developing Countries. London: Zed Books. https://library.wur.nl/WebQuery/titel/927724

United Nations. General Assembly. (1995). The universal declaration of human rights (Vol. 1). United Nations Dept. of Public Information. http://www.un.org/en/universal-declarationhuman-rights/

Azadkhani, P. \& Ziary, Y. (2014). Satisfaction lowincome housing projects in llam. Niaresh international conference on sustainable cities https://www.civilica.com/Paper-SCIENCO1-

SCIENC01 017.html

Azizi, M. (2004). The index of housing in housing planning process. Visual Art Journal, (17), pp. 31-42.

Devrim, I. A. (2016). Housing policies in Turkey: evolution of TOKI (Governmental Mass Housing Administration) as an urban design tool. Journal of Civil Engineering and Architecture, 10, 316326. 7359/2016.03.006

Djebarni, R., \& Al-Abed, A. (2000). Satisfaction level with neighbourhoods in low-income public housing in Yemen. Property management, 18(4), 230-242. https://www.emeraldinsight.com/doi/full/10.11 08/02637470010348744

Doroudi, M. J., \& Shahriari, L. S. (2014). Measuring satisfaction housing residents with urban management approach. Journal of Urban Economics and Management, 3(9), 125-141. http://iveam.ir/browse.php? a id=1 10\&sid=1\&s/ c lang $=\mathrm{fa}$

Evans, G. W., Wells, N. M., \& Moch, A. (2003). Housing and mental health: a review of the evidence and a methodological and conceptual critique. Journal of social issues, $59(3)$

475-500.

https://spssi.onlinelibrary.wiley.com/doi/full/10.1 $111 / 1540-4560.00074$

Ghanbari, A. Zaheri, M. (2010). Assessment of housing policies in programs before and after the Islamic Revolution of Iran, 29 (132), pp. 77 90.

https://www.sid.ir/fa/journal/ViewPaper.aspx?i $\mathrm{d}=124356$

Ghanbari, A. (2013). An Analysis of Locations for Mehr houses in Tabriz city. Journal of Geography and Planning, 20 (55), pp. 229-254. http://geoplanning.tabrizu.ac.ir/article 4744.ht $\underline{\mathrm{ml}}$
Hesamian, F., Etemad, Giti., Haeri, M. (2004). Urbanization in Iran.7 th $\mathrm{ed}$. Tehran. Informed publishing.http://library.um.ac.ir/index.php?opt ion=com _lib\&view=searchextrainfo \&Type $=$ auth or\&DoclD $=1195615 \&$ lang $=\mathrm{fa}$

Hulchanski, J. D., \& Network, F. (2002). Housing policy for tomorrow's cities. Ottawa: Canadian Policy Research Networks. http://www.urbancentre.utoronto.ca/pdfs/rese archassociates/Hulchanski_Housing-PolicyC.pdf

Isalou, A. A., Litman, T., Irandoost, K., \& Shahmoradi, B. (2014). Evaluation of the affordability level of state-sector housing built in Iran: case study of the Maskan-e-Mehr project in Zanjan City. Journal of Urban Planning and Development, 141(4), 05014024. https://ascelibrary.org/doi/pdf/10.1061/(ASCE) UP.1943-5444.0000235

Karimzadeh, A., Shahriari, S., \& Keshtkaran, P. (2015). The Study of Low-Income Housing Residents' Satisfaction. In Managing Intellectual Capital and Innovation for Sustainable and Inclusive Society: Managing Intellectual Capital and Innovation; Proceedings of the MakeLearn and TIIM Joint International Conference 2015 (pp. 643-650). ToKnowPress. http://www.toknowpress.net/ISBN/978-9616914-13-0/papers/ML15-127.pdf

Karshenasan, A., \& Beiranvand, M. (2013). A review on weaknesses and strengths of delivering Mehr housing project in terms of achieving economical goals. Management Science Letters, 3(9), 2521-2530. https://www.researchgate.net/publication/307 676013_A_review_on_weaknesses_and strengt hs_of_delivering_Mehr_housing_project_in_term s_of achieving economical goals

Katz, B., Turner, M. A., Brown, K. D., Cunningham, M., \& Sawyer, N. (2003). Rethinking local affordable housing strategies: lessons from 70 years of policy and practice. Washington, DC: The Brookings Institute. https://www.brookings.edu/wpcontent/uploads/2016/06/housingreview.pdf

Kutty, N. K. (2005). A new measure of housing affordability: Estimates and analytical results. Housing policy debate, 16(1), 113-142. https://doi.org/10.1080/1051 1482.2005.9521536

Mazloom Khorasani, M., Noghani, M., \& Kishbafan, F. (2011). The Study of the Socioeconomic Participation in Mehr Housing Cooperatives and its Effective Factors in Mashhad City in 2009-2010. Applied Sociology, $22(4)$,

44.

http://jas.ui.ac.ir/article_18247_36c41b21137951 084ade2231b3b0d47a.pdf

Nastaran, M. Ranaei, Ahad. (2010). Analysis of the concept of collaboration and teamwork in 
project preparation Mehr housing land. Architecture and Urban Utopia,3 (4), pp. 111123.

\section{http://www.magiran.com/view.asp?Type=pdf} $\& \mid \mathrm{D}=899385$

Okpala, D. C. (1992). Housing production systems and technologies in developing countries: A review of the experiences and possible future trends/prospects. Habitat International, 16(3), 9-32. 3975(92)90060-C

O'Neill, P., Sliogeris, E., Crabtree, L., Phipps, P., \& Johnston, K. (2008). Housing affordability literature review and affordable housing program audit. Sydney: University of Western Sydney: Urban Research Centre. http://www.uws.edu.au/_data/assets/pdf_file/ 0004/164623/landcom report 2008-07-21.pdf

Pour Mohammadi, M. Asadi, A. (2014). Assesment of Mehr housing project in Zanjan. Applied Research of Geographic Sciences, 14(33), pp. 171-192.

https://jgs.khu.ac.ir/browse.php?a_code=A-103-246\&slc lang=fa\&sid =1

Pugh, C. (2001). The theory and practice of housing sector development for developing countries, 1950-99. Housing Studies, 16(4), 399423. https://doi.org/10.1080/02673030120066527

Rafieean, M., Ajilian, S., Aghasafari, A. (2014). Principles, Dimensions and Residential Satisfaction Variables in Mehr Housing Planning (Case Study: Mehregan Township). Quarterly journal of urban studies of Kurdistan University, 5 (19),

pp.27-36.

http://urbstudies.uok.ac.ir/article_33396.html

Rasoolimanesh, M., Jaafar, M., \& Badarulzaman, N. (2013). Urban Planning and Management System in Iran: A Review and Assessment. Middle-East Journal of Scientific Resarch, 18(2), 220-229.

10.5829/idosi.mejsr.2013.18.2.12435

Rezaei, M., \& Kamaeezadeh, Y. (2015). Assess the appropriateness of spatial plans in Mehr housing in Yazd city. Journal of Geographical Research. 30 (3), pp. 275-295. http://eds.b.ebscohost.com/eds/pdfviewer/pd fviewer? vid=0\&sid=4dcd3eb4-2d9f-481 a-8e9033 ceb0035af1\%40sessionmgr104

Saeedi, R. N., \& Kazemi, D. (2011). Recognition within the framework of infill development in criticizing the current policies towards housing development (Maskan-e-Mehr) (Case Study: Natanz

City).

https://www.sid.ir/en/journal/ViewPaper.aspx?! $\mathrm{D}=196631$

Saremi, H. Ebrahimipour, M. (2012). Housing indices of the Iran and the World (A Case Study of Iran, Britain and France), 6 (10), pp. 91-102.
https://www.sid.ir/Fa/Journal/ViewPaper.aspx?! $\mathrm{D}=184861$

Schill, M.H. (2005). Regulations and housing development: What we know. Cityscape, pp.519.

Shahri, M. (2015). The impact of state policies on social housing and urban identity: The case of Maskan Mehr in Urmia. Middle East University. https://www.jstor.org/stable/20868570

Sharifinia, Z. Noura, M. Sangdel, M. (2011). Empowerment and organization of informal settlements, with an emphasis on economic, social, physical and environmental factors Case Study: Goat Hill neighborhood Ghulam city Azadshahr. Geographic territories, scientific - research Journal, 8 (30), pp. 121-134. https://www.sid.ir/En/Journal/ViewPaper.aspx?! $\mathrm{D}=246686$

Wang, Y. P., \& Murie, A. (2011). The new affordable and social housing provision system in China: implications for comparative housing studies. International Journal of Housing Policy, $11(3)$, 237-254. https://doi.org/10.1080/14616718.2011.599130

Weihe, W. H. (1990). Climate change and human health. In Climate and Development (pp. 409432). Springer, Berlin, Heidelberg. https://link.springer.com/chapter/10.1007/9783-642-45670-1_33

Azizi, M., \& Yar Mohammadi, S. (2011). Evaluation of housing land preparation Bojnoord. National Conference on Sustainability and Urban Development

https://ifaup.ut.ac.ir/article 55396 7459.html

Zanjani, H. Golkar, Z. Mohammadi, H. (2011). Social aspects of Mehr Housing case study: Karaj city. Cooperation Journal,22 (7), pp. 89115. http://ajcoop.mcls.gov.ir/article_8885.html

Zareian, M. (2011). Study on Housing in Iran and Germany look to housing construction. Journal of Engineering Organization. https://www.bhrc.ac.ir/ مقالهـ//agentType/ View/PropertylD/4745

Ministry of Roads \& Urban Development Islamic Republic of Iran (2018, Feb) URL 1: Maskan.mrud.ir.

Google map (2017, Dec) URL 2: https://www.google.com/maps/@35.1410321,3 3.9146153,15z

Khorasan Razavi Mehr Resistance Resistance against Earthquake URL 3: http://www.irna.ir/fa/News/82818275

Farda (2018, Jan ) URL 4: https://www.fardanews.com/fa/news/601957/

Planyab (2018, Jan) https://planyab.com/downloads/category/arc hitect/ 